\title{
Aktywne elewacje jako element wpływający na rozwiązania funkcjonalne i formalne w architekturze współczesnej (wybrane zagadnienia)
} Active elevations as an element that influences functional and formal solutions in contemporary architecture (chosen issues)

\begin{abstract}
Streszczenie
Tematem artykułu jest próba refleksji nad rozwiązaniami stosowanymi we współczesnej architekturze w zakresie aktywnych elewacji i ich konsekwencji dla formy i funkcji obiektu. W perspektywie historycznej przenalizowano proces zmian znaczenia elewacji w architekturze okresu modernizmu, postmodernizmu, oraz rozwiązaniach najnowszych. W artykule omówiono wybrane przykłady związane z zastosowaniem fasad kurtynowych i ścian dwupowłokowych, ornamentyką na elewacjach szklonych, dozowaniem dostępu światła naturalnego, powłokami i membranami, interaktywnymi iluminacjami i multimediami, łączeniem elewacji interaktywnych z zielenią. W końcowej części podsumowano przeprowadzone rozważania.
\end{abstract}

\footnotetext{
Abstract contains the summarized reflection on this matter.

Keywords: Elevation, contemporary architecture, architectural composition

Słowa kluczowe: Elewacja, architektura współczesna, kompozycja architektoniczna

\section{Elewacja jako element aktywny}

Elewacja jest w przegrodą, która dzieli i łączy świat zewnętrzny z wnętrzem budynku. Z continuum przestrzeni wydziela mikroprzestrzeń, w której człowiek buduje rozwiązania sprzyjające jego bytowaniu. W takim ujęciu kluczowym wydaje się być dychotomiczny charakter elewacji - elementu, który równocześnie dzieli i łączy. Dychotomię tę próbują przezwyciężyć niektóre ze współczesnych rozwiązań, nadając elewacjom cechy fizyczne i estetyczne, które ulegają zmianie w trakcie procesu użytkowania.
}

The subject of this article is an attempt to reflect upon active elevations' solutions used in modern architecture and the consequences for form and function of a building. The process of changing the importance in modern, postmodern and contemporary architecture was analysed in historical perspective. In this article the author elaborates chosen examples that are connected with using solutions such as curtain- and two-layered walls, glass elevations' ornamentation, controlled access to daylight, tensile structures and membranes, interactive illuminations and their connection with vegetation. The last segment

\section{Elevation as an active element.}

Elevation is a barrier, that separates and connects the outside world and the inside of a building. From the space continuum it isolates the micro space, in which the man creates the ways to improve it's existence. In this sense the most important seems to be dichotomic character of an elevation - the element that both separates and connects. This dychotomy is tried to be overcome by some of the newest inventions, that give the elevations physical and aesthetic features, which change over time. 
Istotną cechą rozwiązań części idei architektury modernistycznej stała się pró przestrzeń wnetrza i zewnetrza. Jednak cześć tych rewolucyjnych idei, pomimo ich niewatpliwych walorów, napotykała na problemy techniczne w realizacji1. Dopiero rozwój tradycyjnych technik budowlanych, które sprzegły sie z rewolucia cyfrowa przełomu XX $\mathrm{i} X X I$ w., dało szanse na urzeczywistnienie historycznych wizji, oraz otworzyło nowe, dotychczas nieeksplorowane obszary. 2. Rola elewacji i jej zmienności w architekturze współczesnej
W znaczacej czéści przykładów architektury historycznej elewacje pełnity funkcję ściany konstrukcyjnej. Biorąc pod uwagę najcześciej stosowane materiały budowlane (konstrukcje ceglane, murowane i drewniane) w znaczący sposób ograniczało to możliwości wprowadzania dużych przeszkleń ${ }^{2}$. Rówczało to możliwości wprowadzania dużych przeszkleñ nocześnie jednak podkreślić należy stosowanie $w$ architektunocześnie jednak podkreślić należy stosowanie $\mathrm{W}$ architektu-
rze cywilnej rozwiązań dozujących dostęp światła dziennego rze cywilnej rozwiązań dozujących dostęp światła dziennego
(np. okiennice i ażurowe przysłony), a w architekturze militar(np. okiennice i azurowe przysłony), a w architekturze militar-
nej osłon chroniących - które uznać można za prototypowe nej osłon chroniących - które
elementy aktywnych elewacji.

elementy aktywnych elewacji.
W połowie XIX W., wraz z rozwojem rewolucji przemysłowej, W połowie XIX w., wraz z rozwojem rewolucji przemysłowej, pojawiają się nowe technologie budowlane, które pozwolity na szersze stosowanie wielkopowierzchniowych przeszkleń. Za symboliczne $w$ tym zakresie uznać można zastosowanie żeliwnych i szklanych prefabrykowanych konstrukcji użytych m.in. przez Josepha Paxtona w Crystal Palace (1851). Kluczowym dla dalszego rozwoju form elewacji i sposobu ich przeszkleń okazało się wprowadzenie konstrukcji słupowych. Idee te podjęte zostały przez twórców Szkoły Chicagowskiej, którzy wypracowali nowe schematy rozwiązań elewacyjnych. Od tego momentu obserwować można dążenia do zmaksymalizowania powierzchni przeszkleń w elewacjach budynow wysokich ${ }^{3}$ leko idace konsekwencie dla rozwoju architektury XX $w, w$ tym także dla sposobów kształtowania elewacii, stał sie stworzony przez Le Corbusiera w latach 1914-1915 system Dom-lno. Jogo założenia wpłyneły na sformutowanie pieciu punktów archite tury nowoczesnej i pozwolity na swoiste „uwolnienie elewacji” tury nowoczesnej i pozwolity na swoiste „uwolnienic

W okresie międzywojennym zaczyna się także tworzyć inny W okresie międzywojennym zaczyna się takìe tworzyć inny

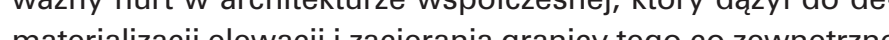
materializacji elewacji zacierania granicy tego co zewnętrzne i wewnętrze. Zasady te realizowane były w głównej mierze poprzez wprowadzanie płaszczyzn szklonych. Klasycznym przedstawicielem tego nurtu był Ludwig Mies van der Rohe, który idee te podejmowal juz $\mathrm{W}$ projektach niezrealizowanych wieżowców ze stali i szkła przy Friedrichstraße w Berlinie (1919), niezrealizowanej koncepcyjnej willi z cegty (1923), a także w pawilonie niemiecki na międzynarodową wystawe w Barcelonie (1929) i ikonicznych dla stylu międzynarodowego amerykańskich projektach budynkow wysokich przy Lake Shore Drive 860-880 (1948) w Chicago (1948) i Seagram Building (1954) w Nowym Jorku. We wszystkich tych koncepcjach dążył on do stworzenia elewacji, która pozwalałaby na połączenie wnętrza z krajobrazem naturalnym lub miejskim. Idee te, odpowiadające doktrynie stylu międzynarodowego,
The significant feature of the modern architecture' thought was an attempt to create the ways to incorporate interiors and exteriors. But the part of these revolutionary ideas, despite their clear positive aspects, met various technical difficultie when executed ${ }^{\text {. Not until the building techniques }}$ progressed, becoming coupled with digital revolu-
tion at the turn of the $X X$ and $X X I$ century, were the historical visions achievable and yet undicovered areas became open

\section{The role of an elevation}

In most of historical architecture examples elevations functioned as load-bearing wall. Regarding he most frequently used construction materials (bick and wooden structures) the possibilities of neously the use of various solutions ${ }^{2}$. Simultathe access to the daylight (for exmple shuter especially in civil architecture, should be highlighted, as well as using the protecting bovers in military architecture - which can be considered as prototypical elements of an active elevations. In the mid-XIX century, together with the development of an industrial revolution, the new technologies emerged, which allowed to widen the usage of a bigger transparent surfaces. Cast-iron and glaze prefabricated structures, used for example by Josep Paxton in Crystal Palace (1851), can be also seen a symbolic. The key to the development of elevation's form and the ways it was made transparent turne notion was later carried out by Chica and lintel. This chitects, who developed a new elevation schemes. From this moment the movement to maximize the area of a transparent surfaces in high buildings has been noticed ${ }^{3}$. Radical theoretical statement, which turned out to affect greatly the development of the XX century architecture and the ways to form an elevation, was created by Le Corbusier in 1914-1915 Dom-Ino House. His assumptions impacted the later formed Five Points Of Architecture and allowed to free the elevation and provided it's compositiona and functional autonomy.

In the interwar period the other important style in terialization of an elevation which led to the demaof what's inside and outside, had started to form. These rules were mostly realised through the implementation of glass surfaces. The classic represent ant of this style was famous Ludwig Mies van de Rohe, who picked up some of the ideas in his unrealised Friedrichstraße Skycraper project in Berlin (1919), unrealised conceptual Brick Country House (1923), and also in his Barcelona Pavilion (1929) and iconic for the international style american hig buildings projects at the Lake Shore Drive 860-880 (1948) in Chicago (1948) and Seagram Building towards creating an elevation, which could conned the interior and natural or urban landscape. These ideas, which fit into international style' doctrine met with huge positive response from architects from spotkały się z szerokim rezonem wśrod architektów na całym być domy jednorodzinne autorstwa Richarda Neutry i innych architektów modernistycznych pracujących w okolicach Kalifornii i Los Angeles w okresie międzywojennym i tuż po zakończeniu II wojny światowej. Ich projekty dążyły do integracii wnetrza $z$ otaczajacym budynek krajobrazem, tak aby uzyskać wrażenie jedności.

Należy zauważyć, że $w$ architekturze XX w. istniały także Należy zauzizc, że w architekure $X X \mathrm{w}$. istniały także definiowani elewacii ijejsymbolicznego znaczeni. Wy druge pow $X$ w tendencje te przejagiej wow w azcumiane whili C. Johnson posul. Philip c. John

Oez które z dzisiejszej perspektywy uznac można za szczególnie wazne dla wspótczesnych form elewacji aktywnych. Pierwszym z nich były narodziny i rozwoj architektury high-tech. Architekci tego kierunku w sposob naturalny eksplorowa możliwosci i nowe pojawiające się technologie. Druga, pozornie odmienną tendencją, okazało się pojawienie się rozwiązań ekologicznych w projektowaniu architektonicznym. $W$ pierwszej fazie idee ekologiczne związane były $z$ kontestacją stechnicyzowanego świata i oparte w znacznej mierze o tradycyjne materiały budowlane. Jednak współcześnie doszło do połączenia tych tendencji i w XXI w. mówić możn wręcz o eco-high-tech i projektowaniu które łączy wykorzystanie najnowszych technologii z dogmatyczną wręcz troską o ochronę środowiska naturalnego.

\section{Fasady kurtynowe i sciany dwupowłokowe} ry $i$ kości wymaga traktowania przegrody zewnetrznej nie tylko jako przeszklenia zapewniajacego optymalny kontakt $z$ otoczeniem, ale podobnie jak czyni to skóra cztomieka jako przegrody od niesprzyjajacych warunków atmoserycz(a) odynku oznacza to traktowani fasady rómnocześnie jako izolatora i źródta pozyskiwania energì Nastepcelch szkleni 4 i proby twse ni bufor powietrza, który pozwalałby na kontrole dostepu ciepła i światta dziennego.

Najczęstszym schematem jest stosowanie przeszklenia wewnętrznego w świetle kondygnacji, natomiast elewacja zeWhętrzego $w$ swietle kondygnacji, natomiast elewacja zePrzy zapewnieniu właściwej wentylacji powietrza pomiędzy

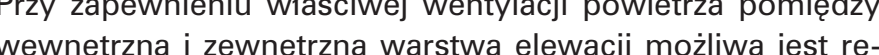
whętrzną i zewnętrzną warstwą elewacji mozliwa jest re gulacja zysków ciepła i dostępu światła dziennego. Sprzężenie ciepła powstającego w buforze między elewacjami może przyczyniac się do realizacji budynkow o tzw. „zerowym zapotrzebowaniu energetycznym" i poprzez zmagazynowanie ogrzanego powietrza w ciągu dnia, słuzyć ogrzewaniu budynku w nocy. Odwrotnym procesem jest przejmowanie przez pierwszą warstwę szklenia ciepła i traktowanie powietrza jako all around the world. One of the most meaningful examples of this 'search" may be single-family houses by Richard Neutra and other modern artists that worked in California and Los Angeles during the interwar period and just after the II World War end. Their projects, similarly to Mies, seeked for looking achieve an impression of unity. It should be noted that in the XX century architec-
ture the opposed trends also existed, which referred to traditional defining of an elevation and it's symbolic meaning. In second half of the $X X$ century mostly manifested in postmoder and widely understood traditional architecture. Some atists like Robert Venturi or Philip C. Johnson postulated the return to the hierarchization of Since then and the primacy of it's meaning.

styles emerged, which and 1970s the two main corrarly significant for later proven to be parttive elevations. The first one was the birth and

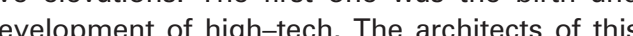
style explored the possibilities and the newcom ing technologies in the natural way. The second seemingly different tendency turned out to be the emergence of an ecological architectural solutions. In the first phase the ecological ideas were in opwosition to the technological view of the world and were based heavily on traditional building materi.lan . echnologies with kind of dogmatic-like concerns for environmental protection.

\section{Curtain- and two-layered walls}

The skin-and-bones idea, that was fundamental for modern architecture, required the usage of the exterial partition not only as the glazing that similarly to himal contact with the exterior, but, vider from unfar thespheric conditions, specifically including the regulation of supply and outflow of a heat. In case of a building, it means the facade simultaneously as an insulator and the source of power generation. This thinking attempt to crete system having indirect fer, which could allow to control the access to heat and daylight.

The most common scheme is the usage of an inside glazing in the clear storey, while the outer facade is led for the entire height of a building With the assurance of a well done air ventilation between inter and outer layer of the elevation it is possible to regulate the gains of both heat and daylight. The coupling of the heat, that forms in buffer between the elevations, may contribute to realising the buildings that have so-called 'zero ennight through storing the air heated within the in The opposite process is taking over heat by the first layer of the glazing and treating the ar as an ventilated insulator (pic. 1). For effectivity improve- 


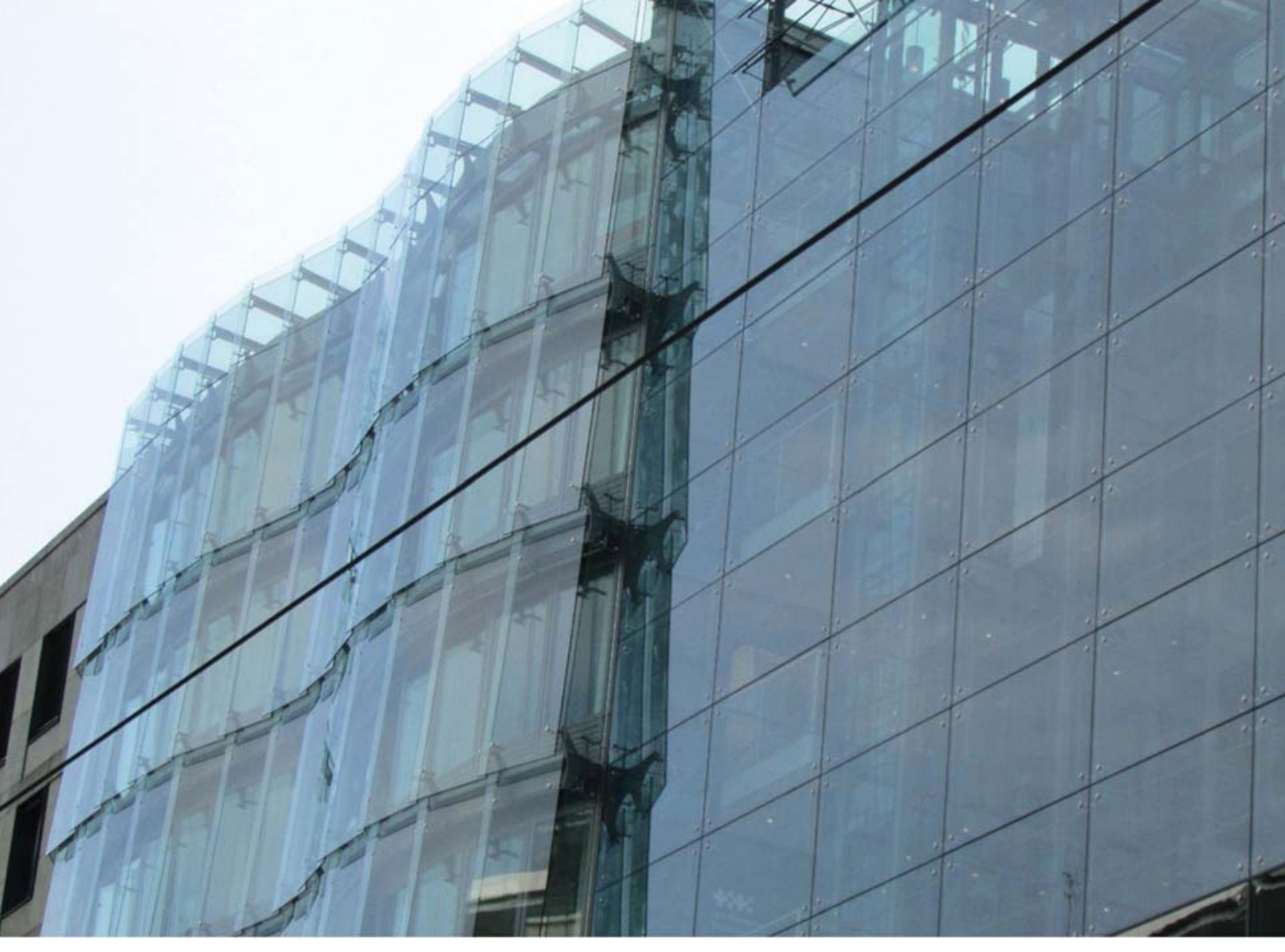

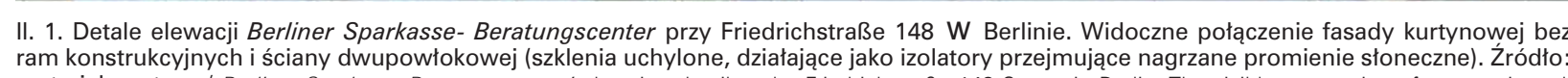

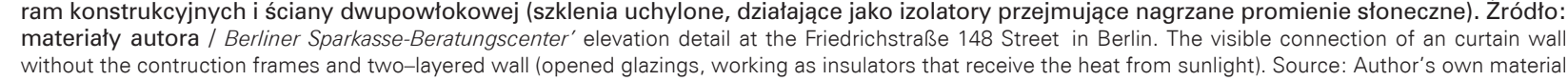

wentylowanego izolatora (il. 1). Dla poprawy efektywności systemy dwupowłokowe wyposaża się dodatkowo w kurtynowe zasłony i zacieniacze, oraz zróżnicowane pod względem grubości, oraz stopnia przeźroczystości szkło

Wart odnotowania jest fakt, że stosowanie powyższych systemów dotyczy zarówno nowych budynków, jak i stosowane jest w pracach rewitalizacyinych. Rozwiazania takie w istotny sposób wpływaja na wyraz estetyczny architektury. Pierwsze ściany dwupowtokowe zastosowano juz w poczatka XX $X$ sle są one wciaż twórczo modyfikowane. Poza typochymi w. wiazani phaszcyzn szknych pojaij sie takze projekty wiaza on wciaz twôrczo modyfikowa ktore proponuja węcz pionierskie formy. Przykładem nowasyteckego 41 Cooper Sauare (2006-2009) w Nowy J ursyteckiego 41 Cooper Square (2006-2009) W Nowym Jorku, która zaprojektowana zostala przez amerykańską pracownię

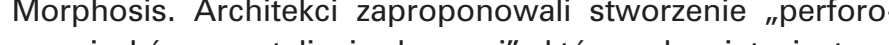
wanej skóry ze stali nierdzewnej", która odsunięta jest od szklanej elewacji. W budynku wprowadzono m.in. magazynowanie wody deszczowej, panele grzewcze i chiodzące, zielony dach i doświetlone atria, które pozwolity na zmniejszenie zapotrzebowania na światło naturalne i sztuczne. Najważniejszym osiągnieciem architektów wydaje się jednak stworzenie formy architektonicznej, która nie kopiuje znanych już rozwiązań, ale wyznacza nowe horyzonty formalne i funkcjonalne.

\section{Nowa ornamentyka}

Zjawiskiem pobocznym, które wymaga jednak odnotowania, stało się wykorzystywanie zróżnicowanych pod względem ment the two-layered systems are equipped with additional curtains and, diverse in terms of thick-

It is worth noting, that using the earlier mentioned systems concers both new and revitalised buildings. These solutions substantially affect on the were already used in the beginning of the $X X$ centsthe typical solutions for glazed planes, the new projects, which offer pioneering forms, still appear. The example of this innovatory architecture may be ex$(2006$ - 2009) in New York, which was designed by the american firm called Morphosis. The architects stainless steel, which would be withdrawn from the glass elevation. They also implemented rainwate storage, heating and cooling panels, green roof and well-exposured atrums, which allowed to decrease biggest achievement of this project seems to be the creation of a new architectural form, which does no copy well-known solutions, but brings a new light into the formal and functional view of an elevation. 4. New ornamentation

The side effect, which although should be noted, turned out to be the usage of varied, from the excould be seen as an attempt of creating kind of new ornamentation, which often has symbolic value: $r y$, but they are still creatively modificated. Besides tension of the 41 Cooper Square' university campu suggested creating 'preforated skin made from wykonawczym nadrukow elewacyjnych. Postrzegac to można jako próbę wypracowania wspó̀czesnej ornamentyki, która najczęściej posiada walor symboliczny.

Pionierami tego zjawiska, którzy podnieśli je do rangi sztuki, są szwajcarscy architekci Jacques Herzog i Pierre de Meuron. W swych pracach z lat 80. i 90. XX w. wykorzystywall oni techniki nadruków przetworzonych motywów fotograficznych na szklanych elewacjach, które odwoływały sie do miejsca i funkcji projektowanych budynków. Jako przyk do

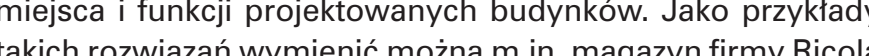
AG (1986-1991) czy też bibliote . Wyższej Szkoty Zawicola . (1986-1991) cay tez bibliogke Wyiszej Szkoly Zawodochodza oni od doslownosci fotografil na rzecz abstrakcyjne ornamentyki. Wprowadzaja oni swobodne, najczęsciej krzywolniowe for Wy, kóre tworzą zmichiajace się wzory na szklanych elewacjach. Do tego nurtu zaliczyc można m. In. bibliotewe KKMZ BTU w Cotbus (2001-2004), cZy whamburskim Hafen City (2007-2016).

Takze $w$ architekturze polskiej znajdują się przykłady wykorzystania podobnych technik. Jednym z najbardziej znanych jest projekt Filharmonit Lodzkiej (2004), autorstwa Romualda Loeglera. Część elewacji w projekcie stanowi szklany łuk, na którym wykonano nadruki historycznego rozwiązania elewacyjnego. Uznać to można za chęć pośredniego przywołania historycznego rozwiązania.

5. Dozowanie dostępu światła naturalnego

Elementem twórczo eksplorowanym w ostatnich dwóch dekadach stało się tworzenie w projektach architektonicznych systemów przesłon, które dozują dostęp światta naturalnego. Ta elementarna aktywność elewacji, wyrażająca sie w architekturze historycznej głównie poprzez systemy okiennic i żaluzii, dała współczesnym twórcom nowe możliwości formalne. Systemy te współcześnie sprzegnięto z innymi funkcjam budynku i wptywaja one także na mikroklimat wnetrza, oraz jego bezpieczeństwo.

jego bezpieczenstwo. Jedną z pionierskich prac wykorysu dozowatie dostępu swiatla wy (1987) autorstwa Jean Nouvela szienci dziennego, zrealizowana tu zostala przy uzyciu autorskiego systemu, kóny odwolywal się do estetyki i dekoracji charakterystycznej dla architektury arabskiej. Przyktadem rozwiązania przeszklonej elewacji, którą można całkowicie zakryc aluminiowymi panelami jest budynek Kiefer Technic Showroom (2007) autorstwa Ernst Giselbrecht + Partner. Budyne ten charakteryzuje się prostotą zastosowanych rozwiązań W elewacji wprowadzono zestaw prostokątnych paneli, któ re napędzane silnikami elektrycznymi pozwalają na całkowite zamknięcie lub odsłonięcie przeszklenia, oraz szereg interesujących pod względem formalnym ustawień pośrednich. Funkcja zacienienia jest szczególnie pożądana w miejscach znaczącej operacji promieni słonecznych. W 2012 r. zrealizowano w Abu Dhabi projekt Al Bahar Towers, autorstwa pracowni Cook + Fox Architects. W budynku zaprojektowano szklaną elewację, ktora może zostac przysłonięta przez układ
The pioneers of this movement, who developed it into an art, are Swiss architects Jacques Herzog and Pierre de Meuron. In their works from 1980s and 1990s they used diverse techniques of an overprinted, graphic and photographic themes on the glass elevations, which referred to a location and a func-

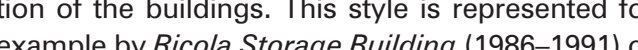
Eherswalde Technical School Library (1993-1996). ater, they departed from the literality of the photography for abstract ornamentation

They present loose, often curvilinear forms, which create changing shapes on their glass elevations. We can also add Cottbus Library (2001-2004) or Elbphilharmonie in Hamburg (2007-2016). Likewise in Polish architecture we can find the examples of using the similar techniques. One of the most famous is the Lodz Philharmonic Hall (2004) designed by Romuald Loegler. The part of an elevaevation wiss of glass arc, on which the historic ela derie to indirectly incorporate the previous form.

\section{Controlling the access to the daylight}

The element that is creatively explored in the last two decades in architectural projects is the creation of a curtain system, which control the access to the daylight. This basic activity of an elevation which was molded in historic architecture mostly by shutters and blinds systems, gave the presen designers a new formal possibilities. Today, these systems were connected with other functions of a building, and they also

an interior and it's safety.

(hed innovatively Institut du Monde Arabe in Paris (1981-1987) by Jean Nouvel. The idea of the metallic brise soleil, which changes it's size and as a consequence allows the diverse amount of daylight to get inside, was realised by using the author's system, which referred to aesthetic and decoration, which was characteristic for arabic architecture. The example of glazed elevation, which could be entirely covered by aluminium panels is Kiefer Technic Showroom (2007) by Ernst Giselbrecht + Partner. This bulding is characterized by the simplicity of used powered by electric engines and which allowed to close or expose the glazing were introduced. An ability to shadow is something very desired in the locations that are very hot. In 2012 Al Bahar Towers by Cook + Fox Architects were realise in Abu Dhabi. The building has a glass elevation, that can be shadowed by the system of spacing out polygonal planes (pic.2), resembling an umbrella in their form. In it's extreme positions it ether covers or unveils the glazed elevation completely. For the formal aspect the most interesting atractive designs, that, besides their appropiable aspect, similarly to how it worked in /nstitu de Monde Arabe through using the geometrica themes, connote the traditional arabic ornamen- 


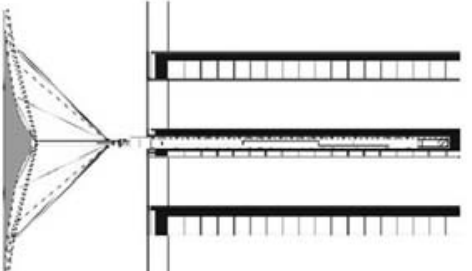

A

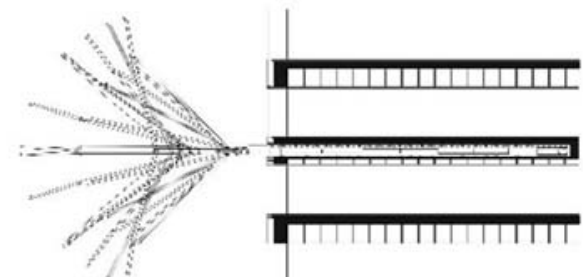

B

il. 2. Schemat wysunięcia płaszczyzn zacieniajacych w budynku Al Bahar Towers, Cook + Fox Architects. A - pozycja petnego zacienienia ele-
wacij szklanej, B - pozycja częściowego zacienienia elewaciji szklanej, C - pozycja całkowitego odstonięcia elewacij szklanej. Żródto: materiaty

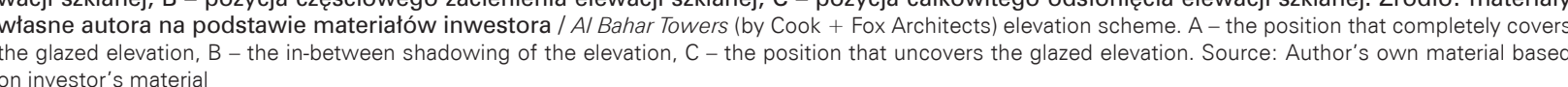

rozkładanych wielobocznych płaszczyzn (il.2), w swej formie przypominających parasol. W skrajnych pozycjach możliwe jest całkowite przysłonięcie oraz otwarcie przeszklonej elewacji. Pod względem formalnym najciekawsze wydają się być tu także ustawienia pośrednie, tworzace interesujące wzory, które poza aspektem użytkowym - podobnie jak to miało miejsce w paryskim Instytucie Arabskim - przez wykorzystanie motywow geometrycznych, przywodzą na myśl odwołania do tradycyjnej ornamentyki arabskiej. Także $w$ architekturze polskiej znaleźć można oryginalne przykłady związane z dozowaniem dostępu światta, a nawet szerzej - „dostępu świata zewnętrznego". KWK Promes Robert Konieczny zaprojektowali Dom Bezpieczny, w którym na życzenie właściciela architekci wprowadził możliwość przesunięć ścian zewnętrznych, w sposób pozwalający na jego całkowitą izolacje.

Elementy mobilnych osłon elewacyjnych mogą znacząco wpływać zarówno na formę, jak i być powiązane z poprawa standardów użytkowych. Ich dalszy rozwój przebiegać będzie zapewne w sposób zintegrowany z kolejnymi możliwościami inteligentnego domu, pozostając jednym $\mathrm{z}$ najbardziej spektakularnym jego rozwiązan.

\section{Eksperymentalne powłoki} Wraz z rozwojem strukturalizmu w architekturze współczesnej popularyzacia ukfáóm powłok i membran. Pionierskie prace w tym zakresie wykonat Richard Buckninst

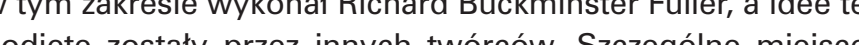
podjęte zostaly przez innych twóców. Szczególne miejsce wrez noszuk pizez innych twócow. Szczedol prez niego badaniateoretycze, przyczy nly się do powstania (1967), czy Stadion Olimpijski w Męe Exo (1972). Tectu (1972). Technologie te dawały szanse kreacji niedostępnych wcześniej dla tradycyjnych materiałów, pozwalając prze wszystkm na nowy Dopiero jednak postęp technologiczny w początku XXI w., związany w głównej mierze z powstaniem technologii powłokowych i okładzin ETFE, które przybrały formę napełnianych gazami (najczęściej suchym, sprężonym powietrzem) membran - otworzyl nowe moźliwossci kreacyjne. Pionierami w tym zakresie po raz kolejny okazali się Jacques Herzog i Pierre de Meuron, którzy w 2005 r. zaprojektowali w Monachium sta-

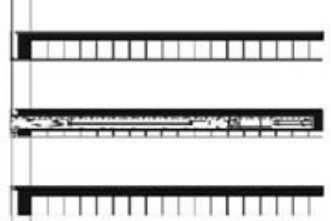

c wanych przez specjalne sprężarki. Atrakcją tego rozwiązania na potrzeby Letnich Igrzysk Olimpiijkich w Pekinie w 2008 koszty uzitkowania. W ostaenich dziesieciu latach pojawito technologil powlokowych, ale elomentem ktory wydaje sie które nie są już nowinkami technicznymi, ale weszły wręcz ave an opportunities to design shapes, that were unavailable with the traditional materials, atwing primarily for innovative covering of a large spaces.

Not until the technological progress in the beginning of the XXI century, which was mostly related to the formation of new covering technologies and ETEE fnishes (which took the form of a cushion filled with air membranes), was this matter picked up. The pioneers of this style once again turned out to be Jacques Herzog and Pierre de Meuron who in 2005 designed famous Allianz Arena in was mad from foil cushions, which are filled with air and pumped with special superchargers. The attraction of this solution is the possibility of invidually backlighting each one of this cushions in various colors, what allows for original illum nation. The similar principle was used also in construction of the Beijing National Aquatics Center $\left(\mathrm{H}_{2} \mathrm{O}\right)$ - olympic swimming pool created for Sum- dion piłkarski, który obecnie nosi komercyjną nazwę Allianz wych poduszek, które napełniane są powietrzem, pompojest możliwość indywidualnego podświetlenia każdej z poduszek na wybrany kolor, co pozwala na uzyskanie oryginalnej iluminacji. Podobna zasade wykorzystano także do budowy Wodnego Sześcianu (H2O) - olimpijskiej pływalni powstat na potzy projektu z CSCEC Internation i. ATW zapropono zali stworzenie systemu blisko Ove Arup duszek - me ro Po raz koleny wykorzysta 3000 poETFE, co pozWolito po raz koleny wykzystano okładziny (atre natu. się szereg innych przyklow wzorystania podobnych być szczególnie istotny jest popularyzacja tych rozwiązan, do masowej produkcji.

Przykładem takich masowych rozwiązań są sferyczne hale kuliste namioty, które przeznaczone są zarówno dla działa czasowych (eventów), jak i realizacji długoterminowych, które są produkowane przez szczecińnką firmę Freedomes (il. 3). Należy przypuszczać, że systemy powłokowe będą $\mathrm{w}$ dalszym ciągu cieszyły się coraz większą popularnoscią. Przemawiają za nimi względy realizacyjne (szybka i stosunkowo prosta konstrukcja), użytkowe (m.in. dobre parametry w zakresie możliwości doświetlenia światłem naturalnym), oraz estetyczne (tworzenie oryginalnych form przestrzennych).

\section{Interaktywne iluminacje i multimedia}

lluminacje architektury stały się od kilku dekad elementem podnoszącym walory estetyczne pojedynczych obiektów odnosząc sie w gtównej mierze do architektury historycznej, pozwalaja one tworzyć wrecz spektakle i powiśsi morycznej, świattem. Nieco odmiennymi zasadami kierują się twórcy

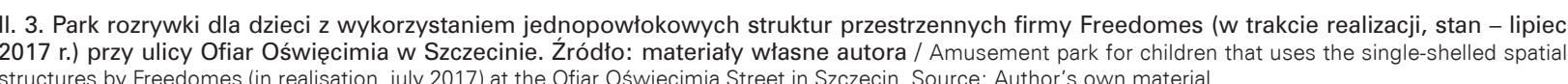

mer Olympics in Beling in 2008. The authors of this project from CSCEC International Design, Ove Arup and PTW proposed forming a system (n) finishes were used and that allow are the er natura light access and better warmth benet whe osts. In the last decade a lot of new examples of similar usage of this technologies emerged, but the element that seems to be particularly important is the popularization of these solutions, on a massive scale.

The example or this mass solutions are spherica halls and tents, which are designed for both shorby Freedomes company (pic. 3 )

(t) systems will still grow. They apuly or these (moderaly easy and quick construction) they are functional (for example good light transparency and aesthetic (various sophisticated shapes).

7. Interactive illuminations and multimedia

The illuminations of an architecture became, since few decades, the element that raises the mostly to the historical architecture, they allow to create kind of performances and stories painted with light. A little different rules were followed by the illumination's creators in new buildings, in which the light systems were the core of the architectural

The examples of this kind of solution may be (19) Yoto by Japhese architect Toyo Ito, located in Yd a prora-

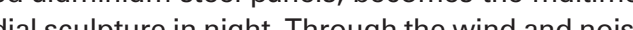
sensors, which are then processed by the comput-

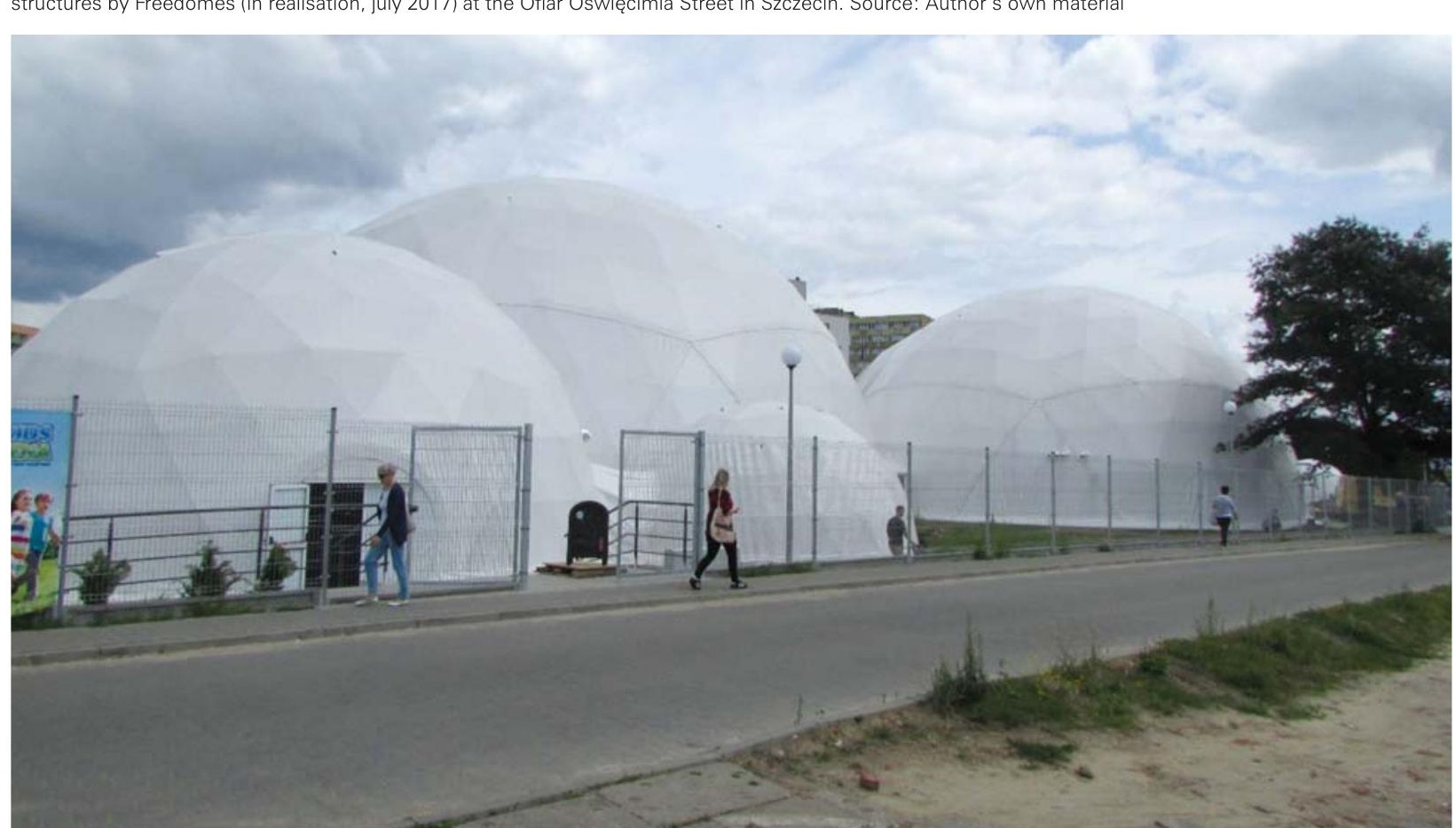
which are not the newest, but are currently used the illuminations that react to the context of the 
iluminacji w nowych budynkach, w których to systemy oświetlenia stanowią wręcz rdzen idei architektonicznych. Przykładem tego typu rozwiązań mogą być iluminacje reagujące na zmieniający się kontekst otoczenia. Klasycznym już rozwiązaniem jest zlokalizowana w Yokohamie Wieża Wiatrów (1988) autorstwa japońskiego architekta Toyo Ito. To technologiczne urządzenie inżynierskie pokryte perforowanymi panelami aluminiowymi staje się nocą multimedialną rzeźbą. Przez czujniki poziomu wiatru i hałasu, które zostają sów do systemu ośmietení i neża iluminuje zróżnicomalsów do syse prosticowane także w projekcie Dexia Tower (2006) w Brukseli, autorstwa także w projekie Dexia Tower (20dy wy Bruksell, autorstwa pracown J.M. Jaspers - J. Eys \& Par Buks, Zaprojektowa-

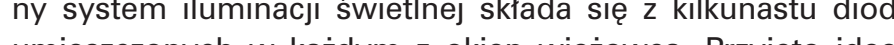
umieszczonych w kazdym $z$ okien wiezowca. Przyęto idee w myst kórej kolor ilumina turę miesięczną, a inny z kolorów opisuje prognozę jej wzrostu lub spadku. Inne zakodowane barwy ilustrują ponadto wilgotność, intensywność wiatrów i opady.

Kolejną z tendencji jest pokrywanie elewacji systemami diod, lub ekranów, które pozwalają na wielkopowierzchniową emisję grafik. Interesujące w tym względzie są projekty holenderskiego biura UNStudio, które wykonano dla koreańskich centrów handlowych. W Seulu zaprojektowali oni Galleria Hall West (2003-2004). W elewacji znajdują się płyty szklane o średnicy ok. $71 \mathrm{~cm}$, które wyświetlają tekst, zdjęcia oraz wielobarwne układy świetlne. Iluminację opartą na sy-
stemie profili i szklanych ekranów UNStudio zaprojektowało także na elewacjach centrum handlowego Galleria Centrcity (2011) w Cheonan. Innym komercyjnym, choć znacznie bardziej kameralnym przykładem, jest tokijski budynek Uniquo (2012), którego autorem jest Katayama Masamichi. Ten japoński twórca znany głównie z projektów architektury wnętrz
zaproponowat realizacje elewacji w formie stalowej kraty, która wypetnit punktami świetnymi. Zmiana nateżenia światta w poszczegónych punktach tworzy grafiki i napisy reklata w poszczegónietlenie we. Oswiel wer (2001-2004) wer (201-2004) wi Wiedniu, au lu Takze i tu zastosowano zasadé punktow skladowych i matryc, których zmienność może być programowana, a jej efekty wy świetlane w sposób dający wraženie plynnej animacji. Przedstawione powyżej przykłady ilustrują zróżnicowane możliwości wykorzystania iluminacji w architekturze współczesnej. U jej źródeł dopatrywać można się intencji artystycznych, ale równocześnie są one obecnie także atrakcyjnymi
nośnikami komercyjnych reklam. Największe możliwości w wykorzystaniu tego typu rozwiazzań daja duże płaszczy-
zny (budowle inżynierskie, bezokienne ściany centrów handlowych), które dzięki iluminacji przestają mieć anonimowy charakter i stają się nowoczesnymi nosnikami informacji. Widoczna jest ponadto ewolucja technologiczna nośników świetlnych. Na początku iluminacje realizowane były poprzez tradycyjne lampy fluorescencyjne, następnie przez oświetlenie typu LED, a obecnie często są to autorskie rozwiązania ekranów cyfrowych. er, the impulses are forwarded to the light system and the tower illumines various colours. The rule of illustration of a weather change was also used in Dexia Tower (2006) in Brussels, by J.M. Jaspers J. Eyers \& Partners. Designed system of light illumination consists of over a dozen diodes placed in was agreed on was that the color of the light would picture the average monthly temperature, and another one would represent it's forecast. The other coded colours would illustrate humidity, intensivity of the wind and rainfal.

The next tendency is to cover the elevation with diode systems or screens, that allow for large graphics emission. The projects of the Dutch UNStudio, which designed many korean shopping centres, are interesting in this respect. In Seoul, they created Galleria Hall West (2003-2004). The glass panels with a diameter of $71 \mathrm{~cm}$, which project the text the elevation. Ilumination, that is based on profil systems and glass screens was also used by UNStudio on Galleria Centrcity's (2011 in Cheonan) evation. Another commercial, but much more private example is the Uniquo (2012) in Tokyo, which was designed by Katayama Masamichi. This japanese artist mostly known from his interior projects proposed the elevation in form of an steel espalie which he later filled with light points. The change of the intensivity in each point creates graphics an advertising banners. The LED light, which is connected with computer screens, became the basis Wien, by HNP Architects. The ruf points and matrixes, which variability may be programmed, and it's effect is shown in a way the simulates the smooth animation.

Examples presented earlier illustrate varied possibilities for using an illumination in contemporary architecture. At it's source we can discern the artistic intentions, but at the same time they are an attractive media for commercial use. The biggest opportunities in using this type of solutions are given by large areas (engineering constructions, window-less walls of the shopping centres), which, thanks to illumination, are finally no an informations. Furthermore, the carriers evolution of the method of lighting At the beginning illuminations were realised by the tradition fluorescent lamps, then by the LED lighting, an now the lighting is often designed by the digita screen's author.

\section{An interaction and social activities}

The development of technology, in conjuction with the artistic imagination, opens a new ways of using elevations as a space for presenting an unconventional artistic activities, which could be used for anusual recreation, but also be the beginning of The examples of this mover

the previous achievement, was, which widened was created for Winter Olympics in Sochi in 2014.
8. Interakcja i działania społeczne

Rozwoj technologii w polączeniu z inwencją twórczą otwier obecnie nowe możliwości wykorzystywania elewacij jako miejsca prezentacji niekonwencjonalnych działan artystycznych, które służyć mogą nietypowej rozrywce, ale także być początkiem procesów rewitalizacyjnych.

Przykładem takiego działania, poszerzającego dotychczasowa dokonania, był projekt przygotowany na Zimowe lgrzysk Olimpijskie w Soczi w 2014 r. Jogo autor Asif Khan zaprojekwa skanowa

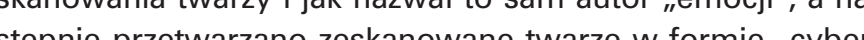
z budynón Nowatorsim elementem z budy kow . Nowa kis cybernetycznych rzeźb" przez wysuwajace sie ze ściany ele"cybernetycznych rzezzb" przez wysuwé

menty, kóre zmirnely swoja dugosc. Działania artystyczne w postaci projekcji mogą także stanowic element strategii $w$ działaniach społecznych. Obecnie $w$ fazie przygotowania znajduje się projekt Mirosławy Jarmołowicz z Akademii Sztuki w Szczecinie. Dzięki dofinansowani miasta Szczecin chce ona prowadzić działania aktywizacyjne w zaniedbanych wnętrzach czynszowych z przełomu XIX IXX w. Jedną z wybranych lokalizacji stało się podwórko przy ulicy K. Kolumba 6 a w Szczecinie. Autorka tak oto formułuje swe idee: Na przyktadzie podworka na Kolumba 6A widac, ze mieszkańcy próbują oswoic swoją przestrzeń, budując miejsca rekreacil, prowizoryczne zadaszenie i altanke, grilla sadząc iglaki, malując elementy małej architektury. Możliwości wejścia ze sztuką mogą być tam różnorodne: galeria na płocie, szereg banerów siatkowych, wystawy czasowe, prezentacje jednodniowe (...), płycinowe drzwi zewnętrzne podwórkowe (...) wypetnione rysunkami wydrukowanymi na ptytach wodoodpornych z rysunkami dzieci tam mieszkajacymi, użycie wtasnych prac jako wydruków wielkoformatowych na ścianach $f^{6}$. Istotna cześcia tego projektu sa realizach o projektu są realizacje wielkoformatow wo ne uniecto poce-

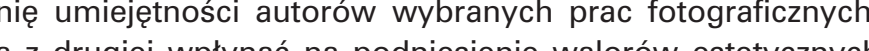
a z drugej wplynać na podniesienie walo fow estetycznych przestrzeni zdegrado czątkować proces ich przemian.

\section{Technologie, arkadie i utopie}

Jednym z nurtów architektury hi-tech, który obecnie uznac można za wręcz najważniejszy, stały się poszukiwania rozwiazań technicznych, które sprzyjałyby środowisku naturalnemu. Pionierskie prace $w$ tym zakresie wykonane zostały m.in. przez niemieckiego architekta Thomasa Herzoga. Wedłu jego założeń powstawać miały budynki łączące naturalne środowisko iwysokie technologie, które nie powinny byc ukryte, ale stanowić integralny element struktury budynku?

W sposób praktyczny idee te reprezentują współcześnie coraz częściej stosowane rozwiązania implantacji zieleni do wnętrz, elewacji oraz na dachy budynków. Jako ikoniczne realizacje $z$ tego obszaru uznac można pionowa scianę zieleni (tzw.
The author, Asif Kham, designed the photographic ( tions' scanning was done, which then was processed in form of 'cybernetic sculptures'exhibite on the one of the building's elevation. The innovative element of this thinking was the actual usage 'sculptures' through elements, that simultaneously slid out and changed their lenght.

The artistic movements, in form of projections may also be an element of strategy in social activities. At present, the project by Mirostaw Jarmołowicz, from Akademia Sztuki (Art Academy) in Szczecin is being prepared. Thanks to the funding by Szczecin city, she wants to activize the inner courtyards from the XIX and XX century. One of the selected locations is the courtyard at the K. Kolumba 6a Street. In the words of author: The example of courtyard at the $K$. Kolumba 6 space, building the recreation spaces, makeshift ed roofing and alcove, the barbeque, planting the conifers, painting the small architecture forms. The possibilities to implement an art may be varied: the gallery on the fence, the number of mesh banners, temporary exhibitions, day-long presentations (...), decorated exterior doors (...) covered by drawings, made by kids that live there, printed on waterproof panels, using own works as large

The influential part of this project is realisation of large photography printouts, which are supposed them on the walls of the courtyard is presumed to in the walls of the courtyard is presumed spaces and (perhaps) begin the proccess of transformation.

Technologies, Arcadia and utopies One of the style in the hi-tech architecture, nowadays recognized as the most significant one, is the esearch for the technical solutions which would be conductive to the natural environment. The pioneering research in that matter was conducted According to his assun architect whomas Herzog. According to his assumptions, emerging building the most innovative technologies, which should ot be hidden, but be the integral part of the building structure

In the practical way, these ideas are nowadays epresented by increasingly used solutions of the mplementation of greenery to interiors, on elevations and roofs. As the iconic realisations on this field, that could be acknowledged, are the vertica green wall ('the living wall') used by Jean Nouvel in parisian Musée du quai Branly (2005), the green garden covering the windowless wall by the Jacques Herzog and Pierre de Meuron due by Renzo Piano, the California Academy of Sciences renovation (2008) in San Francisco where the green roof has been connected with the public spaces. 
living wall) zastosowaną przez Jeana Nouvela w paryskim Musee du quai Branly (2005), zielony ogrod zakrywający bezokienną ścianę autorstwa duetu Jacques Herzog i Pierre de Meuron w centrum CaixcaForum (2005) w Madrycie, czy też zaprojektowaną przez Renzo Piano przebudowe budynku Akademii Nauk (2008) w San Francisco, w której połączono zazieleniony dach z publicznymi wnętrzami.

Jak można przypuszczać budynki te wyrażaja szersza tendencje futurystycznej arkadii, w której poczucie tadu i harmonii potaczone jest z nowoczesna technologia. Wizje than promuje beloijski architekt Vincent Callogia. Wizje przedstawia mista przyszlości jako ptywajace wyspy których ele poróniete sa bujna zielenia Idee elewaci ktorych elewaje porobniç są bujną zielenią. Idee elewacj juz w 2014 r. Jean Nouvel i Parick Barc. W ich projekcie juz w 2014 r. Jea Noul wezowca pry Central Park w Sydney wprowadzil on plaszczyzny zieleni, ktore w polaczen z przeszkleniami wyznaczają nową, innowacyjną tendencję w projektowaniu
budynków wysokich ${ }^{8}$.

\section{Podsumowanie}

Możliwość aktywnych zmian w formach elewacjach obecna była $w$ historii architektury od wieków. Zmiany konstrukcyjne związane głównie z rozwojem i upowszechnieniem konstrukcji słupowych, stworzyły szansę na „autonomizację elewacji” i otworzyły droge do formalnych eksperymentów. Przyczynit się do tego także rozwoj technologiczny, który dotyczy w głównej mierze możliwości realizacji płaszczyzn szklanych. Kolejnymi krokami stały się prób udoskonalenia elewacji jako bufora, który byłby w stanie aktywnie reagować na zmieniające się warunki atmosferyczne, oraz rozwój technologii przysłaniających szklane płaszczyzny. Osobną kategorią stały się działania iluminacyjne oraz cyfrowa zmienność elewacji. $Z$ jednej strony otworzyło to szanse działań artystycznych a nawet społecznych, $z$ drugiej natomiast stało sie naturalnym elementem strategii komercyinych. Elewacje aktywne stały sie takìe wspótcześnie jednym z podstawowych komponentów architektury ekolojiczni Na pày spodziewać sie, że zakrén archich jać sie, a takie pojawia się nowe idee, jac sig, a pazyzej tendencje beda w daszym cingu rozwi Iudzkiej innowacyjnos

PRZYPISY

Przykadem ilustrujacym te problemy może być budynek Centrosojuzu w MosWwielof ktory zaprojektowany zostat przez Le Corbusiera i Pierre Jeannereta. W tym

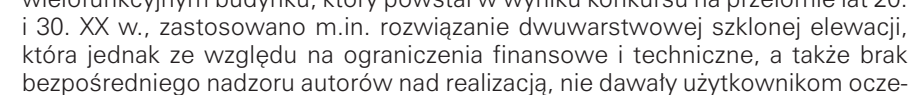
bezpośredniego nadzoru autorów nad realizacija, nie dawaty użytkownikom ocze-

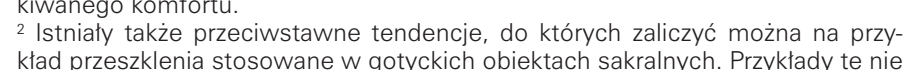
zmieniajaj jednak ogólnej tendenciji, ggodnie $z$ która masowe uizycie wielkoporewoluciji przemystowej.
${ }^{3}$ Choć pamiętać należy, że w wielu rozwiazzaniach elewacji twórcy Szkoty Chicagowskiej stosowali wciaz dekoracie.
${ }^{4}$ Należy podkreslíc takize zmiany jak

列

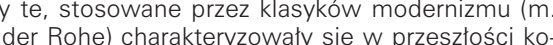
niecznoscia stosowania podziatów na mniejsze pola i osadzania ich w zmodulo-
wanych konstrukcjach ramowych. Wpitywato to bezpośrednio na forme elewacii.
It can be assumed that these buildings express the wider tendency to futuristic utopia, in which the sense of harmony is linked with the modern technology. This vision is promoted by the Belgian architect Vincent Callebaut, who shows the cities of the future as the floating islands, which elevations are overgrown with prostrating greenery, was realized already in 2014 by Jean Nouvel and Patrick Blanc. In their One Central Park residential building project in Sydney, they implemented the green planes which, in connection with the glazing, determine the new, innovative tendency in high rise buildings designe.

\section{Summary}

The possibility to change the forms of elevation have been present in the history of architecture for centuries. Construction changes, connecte f a pol construction ave the opportunity to 'autonomize the elevation' and opened the way to the further research. The technological development, which also contributed in that process, concerned mostly the possibility of implementation of the glass surfaces. The attemps to improve an elevation as a buffer, which would be able to react actively on changing atmospheric conditions, and the development of shading glass surfaces technology were the consecutive steps. The separated category is represented by illumination and digital variability of elevation. On the one hand activities, on the other it became the even socia of commercial strategy Likewise, nowadays active elevations have become one of the essential elements of ecological architecture. The tendencies described above are expected to be still continueing their development. Also new ideas, which are the consequences of the development of technology and first of all inexhaustible human innovation will appear.

\section{ENDNOTES}

The example that illustrates this kind of problems may be
the Centrosoiuz building in Moscow, which was designed by Le Corbusier and Pierre Jeanneret. In this multifiunctional bu ilding, which won the competition on the verge of $1920 \mathrm{~s}$ and
1930 , the architects used two-ply transparent glass elevation,
which due to financial and engineering limitations and without author's supervision was not as comfortable as expected. 2 There were also opposed tendencies, in which we can
include transparent surfaces in gothic sacral buildings. Ho
wever, these instances do not change the general tendercy, according to which the usage of bigger glazed surfaces
was possible due to technical development of an industria revolution

3 But it should be remembered, that in many elevations the
Chicago School architects still used the decoration. ${ }^{4}$ The changes in curtain walls realization that ocurred in the last decades should be noted. These walls, used by the mopast were characterized by the necessity of using partitio ning into smaller areas and moving them into modular frame structures. It directly affected the form of an elevation. The
development of the facades shat lacked the frame structures
caused the further 'dematerialization' of an elevation, which of solar energy transmit-
Rozwoj tasad pozbawionych ram konstrukcyinych spowodowal dalsza, demate
rializacie" ele elewacii, która stata sie elementem jesczze bardziei transparentnym.

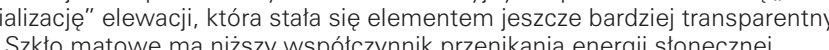

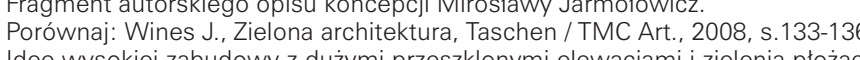
8 Idee wysokiej zabudowy z duzymi praeszklonymi elewacjami i zielenia ptoziaca
wystepuja takze w nowych projektach m.in. Jacquesa Herzoga i Pierre de Meu-
ron, oraz MVRDV.

LITERATURA

11) $10 \times 1022,100$ Architects, 10 Critics, Phaidon, 2006

Digtal Fabrication in Architecture, Laurence King, 2012 ne, medial Ine, Wydawnictwo Polititchnniki Krakowskiej, Czasopismo Techniczne

4] Fiell Ch. i P., Designing The 21st Century, Taschen, 2005.
5] I wamato $0 . .$, Digitial Fabrications: Architectural and Material Techniques, Prince on Architectural Press, 2009

[6] Jodidio P., Building a New Millennium, Taschen, 1999.
7] Khan H.-U., International style. Modernist Architecture from 1925-1965, Tas(8) Kristal M.

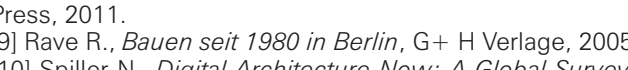
The [12] Wines J., Zielona architektura, Taschen / TMC Art., 2008.

STRONY INTERNETOWE

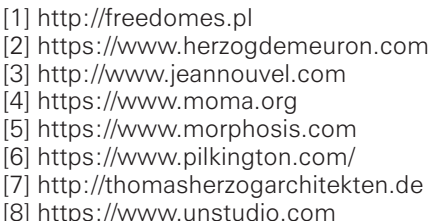

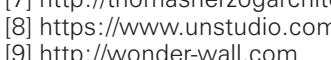

The text excerpt or author's conception' description by Mirpstawa Jarmotowicz
Compare with: $W$ 政 with the large glass elevations and prostrating greenery occur also in inter aria Jac-
ques Herzog and Pierre de Meuron and MVRDV projects.

BIBLIOGRAPHY

[1] $10 \times 102$ 2, 100 Architects, 10 Critics, Phaidon, 2006.
[2] Dunn N., Digital Fabrication in Architecture, Laurence King, 2012.2 - Żak E. Ściany zewnetrzne nowej generaci aktywne, interakktwwne, medialne, Wydawnictwo Politechni-
ki Krakowskiej, Czasopismo Techniczne Z-A4-2007, s. 43-50 [4] Fiell Ch. i P.,. Designing The 21st Century, Taschen, 2005 .
[5] Iwamoto I., Digital Fabrications: Architectural and Material Techniques, Princeton Architectural Press, 2009.
[6] Jodidio P., Building a New Millennium, Taschen, 1999. [7] Khan H.-U., International style. Modernist Architecture
from 1925-1965, Taschen, 2001. [8] Kristal M., Immaterial, World: Tron 196- The

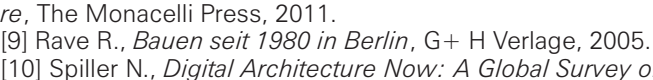
[11] Spiller N, Visionary Architecture: Bluprints of the Modern Imagination, Thames and Hudson, 2008.
[12] Wines J., Green Architecture, Taschen / TMC Art., 2008.

WEBSITES:

11] http://freedomes.pl

2] hittps://www.herrogdemeuron.co

(4) https: / / /Www..juanoma.org

6] https: / /Www.morphosis.com

[7] http://thomasherzogarchit
8) https: //www. unstudio.com
9) http://wonder-wall.com 